\title{
Farmers Household Strategy in Land Conversion Dynamics (Case Study of Penrang District, Wajo Regency, South Sulawesi)

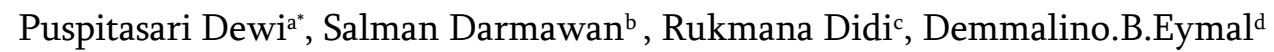 \\ aPost-GraduateStudentsof Hasanuddin University, Makassar, Indonesia \\ a Departemen of Agribusiness, Agricultural Faculty, Unismuh, Makassar, Indonesia \\ bcdFaculty of Agriculture, Hasanuddin University, Makassar, Indonesia
}

\begin{abstract}
The exploding demand for palm oil in the world market makes oil palm expansion in several tropical countries increasingly increasing, especially in Indonesia. The phenomenon of land conversion that occurred in Wajo Regency was caused by the entry of plantation companies which resulted in the shifting of livelihood systems and livelihood strategies. Changing agricultural land into an oil palm plantation area with a partnership system has an impact on the limited community in managing and accessing their land. Farming activities for both rice and other commodities such as cashew and others as well as cattle grazing activities cannot be done on agricultural lands that have been partnered for oil palm plantations. This condition triggered shocks to the farmer's household livelihood system. So that in the process the community carries out various adaptation of livelihood strategies. Therefore, this study aims to analyze the livelihood strategy of the community in meeting household needs before and after the conversion of agricultural land to oil palm plantations. This study uses snowball sampling and in-depth interviews conducted in the village of Taddangpalie, Penrang District. The results showed that the livelihood strategies of farmer households before conversion which had the largest percentage were survival strategies (53\%), consolidation (30\%), accumulative (17\%) with the agricultural basis. After land conversion occurs there is a decrease in the survival strategy phase which is to be (48\%) because some households switch the consolidation phase by (40\%), and the accumulative phase still remains at the percentage, with the dominant basis being agriculture and non-agriculture. Vulnerability in the form of shock, trend, and equality is overcome by two types of strategies namely survival strategies and consolidation strategies by adopting human capital, social capital, natural capital, and financial capital.
\end{abstract}

Keywords : Conservation, Household Strategy, Survival, Consolidation, Accumulative, Vulnarability

\section{INTRODUCTION}

The exploding demand for palm oil in the world market has made the expansion of palm oil in several tropical countries increasing. Indonesia is one of the largest countries producing palm oil. Oil palm plantations in Indonesia increased from around 300 thousand ha in 1980 to around 15.9 million ha in 2016[15]. The vast increase in oil palm plantations in Indonesia is due to an increase in the growth of the palm oil industry at the global level over the past few years. For tropical countries including Indonesia, oil palm plantations are one of the main alternatives to drive the economy besides the oil and gas sector [14,3].

In the past, the area of oil palm for independent farmers was far less than the width of the state and private plantation land. The country still controls the oil palm plantation area of $68 \%$ of the total area of oil palm plantations in Indonesia. From year to year, the area of 
oil palm plantations owned by private and independent farmers is increasingly dominating compared to the plantation area state-owned palm oil. Even in 2013, the area of private plantations already controlled $51 \%$ of the total area of oil palm plantations in Indonesia and $42 \%$ of the land was controlled by independent farmers [5]. The palm oil-based industry contributes greatly to economic growth, poverty alleviation, and improved income distribution. Oil palm development has a positive impact on economic growth as indicated by the growth in investment, output and foreign exchange, increased household income, increased access to infrastructure / social services, and increased land value [9]. The palm oil industry has a significant contribution to household welfare. Besides that, oil palm also provides employment opportunities for the community. Based on data from GAPKI [7] the amount of labor absorbed by the oil palm plantation industry was 7.3 million people in 2013 , increasing to 7.9 million people in 2015.

Behind these positive impacts, it cannot be denied that the presence of oil palm plantations also has a negative impact on environmental conditions, where when environmental damage occurs, local communities around the plantation will experience vulnerability. In addition to changing the agricultural system, the presence of palm oil also causes deforestation, loss of area of food crops, reduced biodiversity, and most importantly, people lose access to manage and utilize the results from the land $[16,19]$.

The phenomenon of land conversion that occurred in Wajo Regency was caused by the entry of plantation companies which resulted in a shift in the livelihoods of livelihood systems and strategies. Wajo Regency is one of the regions in South Sulawesi Province (Indonesia) which in the last six years has converted agricultural land into oil palm plantations. Based on the recommendations of the Wajo District government, the area that can be developed for oil palm plantations is \pm 18,000 ha.

Land acquisition by the company has an impact on community livelihood changes. In general, the community in the research location has a livelihood as farmers by utilizing the surrounding land (58.09\%). The results of previous studies by Amaliah [1] found that changes in the ecological landscape from forests to oil palm plantations put great pressure on the social aspects of society in the form of bundles of rights, land tenure, land tenure structures, non-agricultural livelihoods, and community cohesiveness.

Oil palm plantations in Penrang District affect the livelihood strategies of local communities. The magnitude of the influence on the livelihood strategy of local communities depends on how much the local community can survive and use the livelihoods presented by oil palm plantations. According to Dharmawan [4], each household as the smallest social unit in society is required to be able to face (coping) and adapt (adaptation) with various pressures (stressors) and shocks (shock), as well as maintaining the capabilities and livelihood assets that they have by carrying out various livelihood strategies that are able to guarantee their livelihoods and the next generation. Livelihood strategies are choices formed by assets, access, and activities that are influenced by the capability of a person or household to do so [3,4]. Activities, assets, and access are closely related to structures and processes that show dynamic relationships in determining livelihood strategies. White [21] dividing the livelihood strategy phase into three slopes, namely the survival strategy phase, the consolidation strategy phase, and the accumulation strategy phase.

Based on the phenomenon, this study aims to analyze livelihood strategies in overcoming vulnerability to household needs before and after the conversion of agricultural land to oil palm plantations.

\section{Research Method}

The paradigm in this study uses the postpositivism paradigm with a qualitative approach and the method used is a case study which divides one case in several cases. The case chosen was Taddangpalie Village as a single case. The single case was built from several household case units in it. The analysis unit (informant) is a farmer's household that converts agricultural land 
into oil palm plantations. Determination of informants is done until the saturation point is that no new answers appear from information via the snowball system.

Data collection is done by collecting primary and secondary data. The instruments used are direct observation (observation), in-depth interviews (in-depth interviews) and document studies. The interview process is carried out in a structured manner to gather information on the impact of changes in a conversion of agricultural land to oil palm plantations on the choice of livelihood strategies for household livelihoods before and after land conversion. In the initial analysis, there are Spreadsheets, coding steps and case unit analysis (intro case unit analysis); summary of categories + data reduction $=$ preliminary findings (Summary of categories + data reduction $=$ key findings $)$.

\subsection{Data Analysis}

Data analysis was carried out using White's livelihood strategy framework [21]. In further analysis more directed to the analysis between case units (comparable). Comparative findings of the case unit at the end of the analysis between case units will be concluded. Data processing was also carried out by the triangulation method in which data processing was carried out by the comparison process between secondary data, interview data and results of observation.

\section{Result and Analysis}

\subsection{Characteristics of Informants}

Land resources for farmers are an important factor of production other than financial resources and human resources. Human resources and financial resources will become a natural resource if farmers do not master the land resources for farming. Farmers have a very strong emotional bond with the land where they are working because from the land it is expected to be able to revive the farming family. Farmers will depend all their hopes on what is produced from the land, this relationship is common to farmers who make farming as the only mainstay to support their families.
The characteristics or identity of informants in a study is very important because it will describe the true situation of the informant. The informants in this study are farmers who convert from agricultural land to oil palm plantations as many as 30 households.

From table 1 it is known that the majority (37\%) of respondents aged $41-50$ years, then $27 \%$ between $31-50$ years and a small portion (17\%) aged 51-60, (13\%) aged over 60 years and the rest (7\%) are 20-30 years old. This shows that most farmers in Taddangpalie Village (85\%) are in productive age. This age shows the potential workforce in the village of Taddang Palie is very good, so it has the opportunity to increase development, especially in agriculture.

Farmer households take primary school education (43\%), junior high school (23\%), do not complete elementary school (17\%), high school (10\%), to college (7\%). When observed from the level of formal education, it can be said that farmers in the study area still have a relatively low level of formal education, namely only the primary and secondary levels. The low level of education makes it difficult to find work in the formal sector so that most farmer households have a livelihood as farmers. This shows that the agricultural sector is still a mainstay for families in earning a living. Based on the level of education above, it is also reflected in the characteristics of the main job done by households as farmers $(57 \%)$ followed by the type of work as entrepreneurs (17\%), construction workers (7\%), oil palm workers (10\%), civil servants $(7 \%)$, and weaving craftsmen (3\%).

The biggest percentage of the number of family dependents is $3-4$ people $(46 \%), \leq 2$ people $(26 \%), 5-6$ people (20\%), and 7-8 people $(7 \%)$. So it can be concluded that the average number of farmer family members is classified as moderate. The more the number of dependents of farmer families, the more economic burden that must be borne by farmers. This will encourage farmers to increase the productivity of other businesses in order to meet the needs of families. 
Table 1: Distribution of Respondents based on Farmer Household Characteristics, 2018

\begin{tabular}{|c|c|c|}
\hline Family Characteristics & Farmers (people) & $\begin{array}{l}\text { Percentage } \\
(\%)\end{array}$ \\
\hline \multicolumn{3}{|l|}{ Age (years) } \\
\hline $20-30$ & 2 & 7 \\
\hline $31-40$ & 8 & 27 \\
\hline $41-50$ & 11 & 37 \\
\hline $51-60$ & 5 & 17 \\
\hline$\geq 60$ & 4 & 13 \\
\hline \multicolumn{3}{|l|}{ Formal education } \\
\hline No school & 5 & 17 \\
\hline primary school & 13 & 43 \\
\hline Junior high school & 7 & 23 \\
\hline Senior high school & 3 & 10 \\
\hline College & 2 & 7 \\
\hline \multicolumn{3}{|l|}{ The main job } \\
\hline Farmers & 17 & 57 \\
\hline entrepreneur & 5 & 17 \\
\hline Construction workers & 2 & 7 \\
\hline palm oil workers & 3 & 10 \\
\hline civil servants & 2 & 7 \\
\hline weaving craftsmen & 1 & 3 \\
\hline \multicolumn{3}{|l|}{ Number of Family Members } \\
\hline$\leq 2$ & 8 & 26 \\
\hline $3-4$ & 14 & 46 \\
\hline $5-6$ & 6 & 20 \\
\hline $7-8$ & 2 & 7 \\
\hline $\begin{array}{l}\text { Average Farming Experience (yr) } \\
\text { Min-Maks }\end{array}$ & $\begin{array}{c}19,2 \\
5-30\end{array}$ & \\
\hline
\end{tabular}

farmers to choose better and profitable farming

Based on experience, rice farmer households are experienced enough, between 5-30 or an average of around 19.2 knows. This means that farmers have enough experience and understanding the procedures for rice cultivation. The experience of growing rice is obtained from generation to generation from both parents. Rice farming is very well understood, starting with production problems, farming costs, and income. The experience of low yields, crop failure due to pests and diseases, and the high risk of farming are certainly very influential on the decision of alternatives.

\subsection{Rice Field Conversion in Taddangpalie Village}

The livelihoods of the farmers in Taddangpalie Village are subsistence farmers with rice cultivation and some cashew gardening. The entry of private palm oil company PT. Sinar Reksa Kencana in the last 6 years has had an impact on people's livelihoods. Rice fields that are not supported by an adequate irrigation flow so that the existing rice fields often experience drought and crop failure. Along with that, 
the community was promised by the company with a partnership pattern (40: 60 profit sharing system) where production costs will be borne by the company. So that the public's belief in land conversion increased.

Oil palm plantations are planted on unproductive rice fields, mixed gardens, and pasture fields. This condition changes the function of rice fields into oil palm plantations. At present, the conversion of paddy fields has occurred in almost all land where the availability of water is not sufficient to plant rice. About $\pm 700 \mathrm{Ha}$ of rice fields have been converted into oil palm plantations.

The presence of oil palm plantations in the village of Taddang Palie has a negative impact on the community, the community loses access to their land. Almost part of the community besides working as their farmers also as farmers. The cattle are usually grazed on dry paddy fields. With the conversion of part of the agricultural land, the community loses access to be able to use agricultural land as a breeding ground.

The results of in-depth interviews with 30 rice farmers in the village of Taddangpalie, over the function of rice farming land into oil palm plantations have an impact on their rice yields. This is due to the fact that in many oil palm plantations there are rat pests that attack farmers' paddy fields in the village of Taddangplie. The number of rat pests causes farmers to experience a loss in the shrinking yield of their rice farming land. The farmers have to spend more money to buy rat pests for their land. These mouse pests come because the rice fields of agricultural land are adjacent to oil palm plantations. Such conditions, increasingly encourage farmers to convert land to oil palm plantations and try to find other sources of livelihood to meet the needs of farmers' livelihoods.

\subsection{Changes in Community Strategies Before and After Conversion}

Before the conversion occurred, the survival strategy had the largest percentage of 16 households (53\%), followed by a consolidation strategy of 9 households $(30 \%)$, and the smallest percentage in the accumulative strategy were 5 households (17\%) (Figure 1). All types of survival, consolidative and accumulative are dominated on the agricultural basis. This is in accordance with the condition of Wajo Regency which is one of the rice granary areas in South Sulawesi. In addition to the agricultural base there are also trade bases, oil workers, nomads, traders, and other non-agriculture.

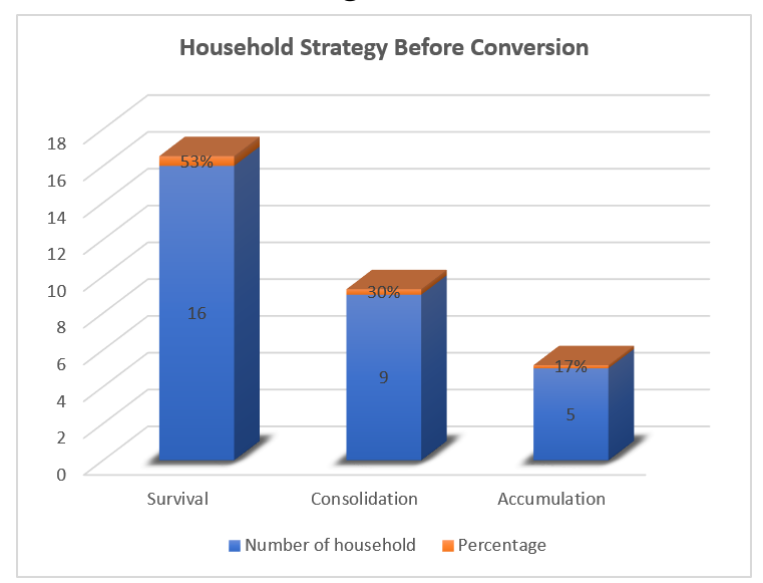

Figure 1: Percentage of Household Livelihood Strategies Before Conversion in Taddangpalie Village

Community livelihood strategies after land conversion have changed, in a consolidation strategy, there are still 9 households (30\%). But there was a shift in strategy, there were 2 households moving from a consolidation strategy to survival with an oil palm and migrant worker base, and 2 households moving to an accumulation strategy. Consolidated households before conversion were almost all based on agriculture and nomads, after the conversion of 
only 2 households that survived on an agricultural basis. Whereas households with survival strategies experienced a slight decline, namely from 16 households to 14 households (47\%). As many as 4 households move into a consolidation strategy with the basis of employment of migrants, traders and oil palm workers. Households with accumulated strategies increased from 5 households to 7 households (23\%) (Figure 2). The work base on this strategy is agriculture, trade, nomads, village officials (village heads and hamlet heads).

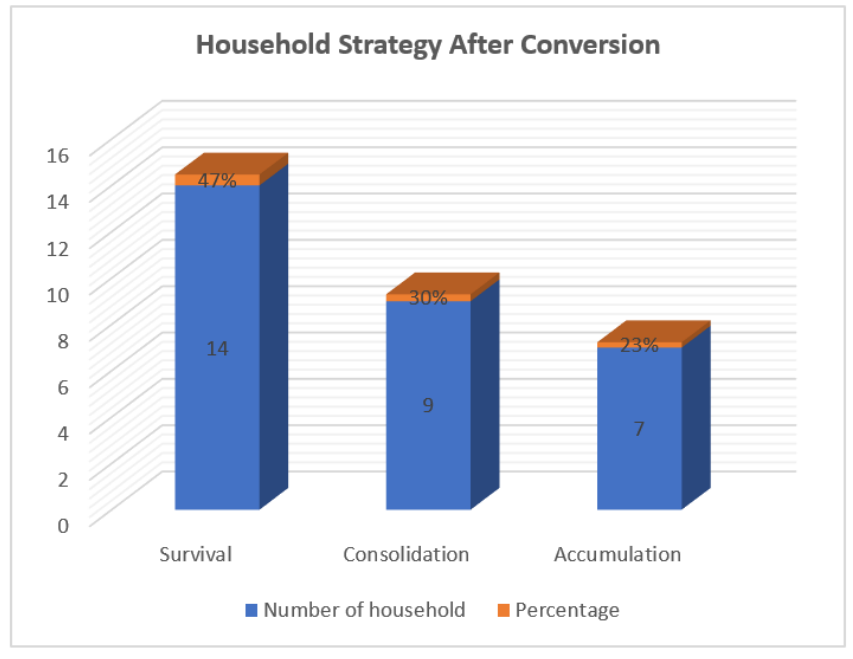

Figure 2 : Percentage of Household Livelihood Strategies After Conversion in Taddangpalie Village

\begin{tabular}{ll}
\hline \\
Base Agriculture \\
Village apparatus \\
Palm Workers \\
Social Capital
\end{tabular}

Caption ${ }^{\circ}$ : Choice of livelihood strategies before conversion

${ }^{\circ}$ : Choice of livelihood strategies after convergingsi

$\rightarrow$ : Indicates the direction of movement

Figure 3 : Movement of Changes in Livelihood Strategies Before and After Land Conversion

\subsection{The Accuracy of Strategies in Resolving Vulnerability}

The results of the strategy accuracy analysis in overcoming household vulnerability after converting land are shown in Table 2. Following 
Table 2: Effectiveness of The Accuracy of Strategies in dealing With Vulnerabilities

\begin{tabular}{lll}
\hline \multicolumn{1}{c}{ Vulnerability Context } & \multicolumn{1}{c}{ Livelihood strategy } & \multicolumn{1}{c}{ Strategy Accuracy Analysis } \\
\hline $\begin{array}{l}\text { Shock (shock): Head of the } \\
\text { household experienced } \\
\text { work accidents when a } \\
\text { palm oil worker. }\end{array}$ & $\begin{array}{l}\text { The role of the head of the } \\
\text { household is replaced by his the right decision to replace the } \\
\text { wife and other family head of the household in earning }\end{array}$ \\
members to fulfill the a living in order to meet the \\
household's living.
\end{tabular}

The implementation of livelihood strategies in addressing vulnerability varies greatly. Farm households not only use the agricultural sector to meet the needs of life but also utilize the nonagricultural sector. Stages in continuing life through a different system of living. Shocks (shocks) that are sudden and unpredictable changes, have a profound effect on livelihood and are destructive or destructive. Generally can be felt directly. When a situation like this happens, the right strategy to do it with a survival strategy. The strategy this is done in various ways to survive, all the results obtained are used to meet the minimum life needs of food [4]. The same thing is expressed by Alviawati [2] that survival strategy as a form of business subsitence, that is as a strategy or art of survival to simply meet the needs daily. 
Once a household is susceptible to vulnerability due to a sudden flaw or a sudden headache, other family members will be involved in earning a living. The results of research by Safitri [12], that all households will tend to increase their labor force participation in common with these findings. Sugiharto[17] argues that the care of large families and traditions helps to be a factor in reducing family vulnerability. But if the concern of the extended family and the tradition of help helps fade, the vulnerability experienced by a family with many resource constraints will increase. Trends are slow changes that are generally predictable but affect the livelihood of the community if it fails to be properly anticipated by the community. It is a complex, non-independent, and accumulated change of conditions. Before feeling the impact of this vulnerability, households usually have implemented several strategies to anticipate vulnerabilities. The right strategy is to consolidate. A consolidation strategy is a strategy that prioritizes the security and stability of revenues from processing resources. This strategy contains household actions that have passed the level of security from just surviving, where they are able to meet subsistence needs[16]. This strategy is done to avoid or anticipate if the earned livelihood is not sufficient to meet the needs of subsistence or needs that are sudden.

In the event of a decrease in activities to access, process and harvest after converted land, households have difficulty obtaining food and conducting cattle/buffaloes. Households without adequate food reserves will fall into vulnerable positions. At times like this, the thing that can be done is to ask for help from the family. Suriastini [18] affirmed the resources that can be allocated by households when feeling the financial crisis crunch can be done by taking credit, taking savings, increasing work time, owing and expecting family assistance.
Asset sales can be used as one of the survival strategies. The sale of assets can be used as a tool for investments such as education, business capital or buying new land. In line with the results of research conducted by Suriastini [18] that the assets of both houses, land, livestock have an important role in the survival of the household. Assets can be used as tools to help households in crisis situations because they can be sold, tucked away or mortgaged.

Seasonal changes are periodic and frequent changes over a period of time. Although it can be predicted that it will generally still have an impact on people's livelihoods, the impact is broader than the ability to anticipate the community. Similar to the vulnerability caused by the trend, seasonal vulnerability (seasonality) is addressed by households by implementing a consolidation strategy because this vulnerability is periodic and has often occurred. This is in line with the findings of Kamaluddin [10] that when a stressor occurs due to extreme climate change, the farmer adapts well by asking for help to the family, migrating, or looking for work elsewhere. Looking for side jobs, other family members participating in earning a living, and making several sales on assets is a strategic option that can be taken to get additional income. The pattern of multiple livelihoods (diversification) can be done by looking for work other than agriculture or mobilizing family labor (father, mother, or child) to work so as to increase the purse of income [17]. Turasih [20] Suggested that the livelihood strategy applied by potato farmers consists of the livelihood strategies of the on-farm and non-farm sectors. The strategy of diversifying the two livelihood sectors is a form of household farmers' struggle in dealing with various situations. Meisanti[11] also found that gold mining in Bombana had brought people to changes in the structure of farmers' livelihoods, farmers slowly began to leave agricultural activities and turned into 
traditional gold miners. Diversifying livelihood means not only being on the main livelihood base but also utilizing time and opportunity outside the base. Utilizing non-agricultural sectors and migrating into one of their ways to supplement income.

Similarly, migration is an effort that is done with the mobility of other areas outside their village. Fridayanti[6] research results show that farmer families in Cipeuteuy village almost $25 \%$ of their non-agricultural income is contributed from transfers of families working outside the village. Migration is one-way household farmers do to support their livelihood strategies.

\section{IV.CONCLUSION}

The livelihood strategy of farmer households before conversion which had the largest percentage was survival strategy (53\%), consolidation (30\%), accumulative $(17 \%)$ on an agricultural basis. After land conversion occurs there is a decrease in the survival strategy phase which is to be $(48 \%)$ because some households switch the consolidation phase by (40\%), and the accumulative phase still remains at the percentage, with the dominant basis being agriculture and non-agriculture. Vulnerability in the form of shock, trend, and equality is overcome by two types of strategies namely survival strategies and consolidation strategies by adopting human capital, social capital, natural capital, and financial capital.

\section{REFERENCES}

[1]. Amalia Rizki. (2016). Perubahan Lanskap Ekologi, Kerentanan, dan Resiliensi Nafkah Rumah Tangga Petani di Sekitar Hutan di KalimantanTimur. Tesis. Sekolah Pascasarjana Institut Pertanian Bogor. 2016.
[2]. Alviawati E. (2013). Strategi Penghidupan Rumahtangga Peternak Sapi Perah Di Desa Kepuharjo Kecamatan Cangkringan Pra dan Pasca Erupsi Merapi. 27 (2).2013

[3]. Castilanco C, Etter A, Ramirez A. (2015). Landa Use Policy Impact of Oil Palm Expansion in Colombia: What do Socioeconomic Indicators Show?. Land Use Policy. Avalaibel from: http;//dx.doi.org/10.1016/j.landusepol.2014.10.0 07.

[4]. Dharmawan AH. (2007). Sistem Penghidupan dan nafkah Pedesaan : Pandangan Sosiologi Nafhkah (Livelihood sociology) Mazhab Bogor dan Mazhab Barat. Sodality. Jurnal Transdisiplin Sosiologi, Komunikasi dan Ekologi Manusia. 01 (02) ; 169-192.

[5]. Direktorat Jenderal Perkebunan-Kementerian Pertanian Republik Indonesia. (2014). Statistik Perkebunan Indonesia 2013-2015: Kelapa Sawit.

[6]. Fridayanti Novia. Rumahtangga Petani Sekitar Kawasan Hutan. (2013). Journal Sodality Sosiol Pedesaan 2013; 01(01); 26-36.

[7]. GAPKI. (2016).Siaran pers : refleksi Industry kelapa Sawit 2015 dan Prospek 2016

[8]. Gatto Marcel, Wollini M, Qaim M. (2015). Oil palm Boom and Land-Use Dynamics in Indonesia. The Role of Policies and Socioeconomic Factors. Land Use Policy. 2015;46;292-303.

[9]. Hansen S.B, Padfield R, Khadijah Syayuti, Stephanie Evers, zuriati Zakaria SM. (2007). Trends in Global Palm Oil Sustainability Research. Journal Clean Prod. 2007

[10]. Kamaluddin A, Ala A, Salman.D. (2012). The Adaptation of Rice Paddy Farmers Towards Climate Change. Am J Agric EnviroSci. 2012;12 (7)967-72.

[11]. Meisanti,Ali Mss, Jusoff K, salman D, rukmana D. (2012). Rticle.The Impacts Of Gold Mining 
On the Farmer's Community 1. 2012; 6 (4); 209-14

[12]. SafitriY. M Esw. (2013). Jaringan sosial dan strategi Adaptasi Tenaga kerja Migran Asal lampung di Desa Jayamukti, Kecamatan Cikarang Pusat, kabupaten Bekasi, Provinsi Jawa Barat. J Sosial Pedesaan. 2013;01(01);6477.

[13]. Saleh, S.e. (2014). Strategi Penghidupan Penduduk Sekitar Danau Limboto Provinsi Gorontalo. Desertasi. Universitas Negri Gorontalo.

[14]. Sayer J, Ghazoul P, nelson A, Boedhihartono K. (2012). Oil Palm Expantion Transform Tropical Landscapes and Livelihoods. Glob Food Sec. 2012;1;114-9.

[15]. Sawit Watch. (2016). Siaran Pers: Moratorium Perijinan Perkebunan Kelapa Sawit Sebuah Langkah Maju Pemerintahan Joko Widodo. 19 Jnuari 2017.

[16]. Srinivas A, Koh Lp. (2016). Oil Palm Expansion Drives Avifaunal Decline In The Pucallpa Region Of Peruvian Amazonia. Glob Ecol Conserv. 2016;7;183-200.

[17]. Sugiharto A. Kerentanan. (2015). Strategi Nafkah, dan Tingkat Kesejahteraan Keluarga Petani di Kecamatan Playen Kabupaten Gunung Kidul. Desertasi. 2015

[18]. Sutriani N. (2010). Kontribusi Strategi Bertahan Hidup Rumah Tangga Pasca-Tragedi Bom Bali I Pada Peningkatan Kesejahteraan Materi : Menggunakan Data Panel Rumah Tangga. 2010

[19]. Tarigan SD, Sunarti Widyaliza. (2015). Expansion Of Oil Palm Plantations and Forest Cover Changes in Bungo and Merangin Districts, Jambi Province, Indonesia. Procedia Environ Sci. 2015;24:199-205.

[20]. Turasih, Kolopaking. L.M.WE. Pada Petani dataran Tinggi (Studi petani di Dataran Tinggi
Dieng, Kabupaten Banjarnegara). J Sosiol Pedesaan. 2016;70-82.

[21]. White B, Boomgaard, $\mathrm{P}$ dan Alexander, P. (Editor). (1991). In Shadow of Agriculture. Non-Farm Activities in the Javanase Economy, Past and Present . Royal Tropical Institute.Amsterdam.

Cite this article as :

Puspitasari Dewi, Salman Darmawan, Rukmana Didi, Demmalino. B. Eymal, "Farmers Household Strategy in Land Conversion Dynamics (Case Study of Penrang District, Wajo Regency, South Sulawesi) ", International Journal of Scientific Research in Science and Technology (IJSRST), Online ISSN : 2395-602X, Print ISSN : 2395-6011, Volume 6 Issue 3, pp. 278-287, May-June 2019. Available at doi : https://doi.org/10.32628/IJSRST196351 Journal URL : http://ijsrst.com/IJSRST196351 